\title{
AN ANALYSIS OF THE EARLY DISCOURSE OF BALINESE PRESCHOOL CHILDREN'S DIRECT SPEECH IN SINGARAJA
}

\author{
I Luh Meiyana Ariss Susanti \\ English Education Department \\ STKIP Agama Hindu Singaraja, Bali, Indonesia \\ meysusanti14@yahoo.com
}

\begin{abstract}
This study analyzes the early language development of young Balinese preschool children in Singaraja. Specifically, the study focuses on the early discourse abilities of the novice language learners. The study involved ten 4 - years - old preschool children and their caregivers (parents, extended family members, and nannies) from Singaraja. The data were analyzed to see what discourse types were used by the children and in what language (Indonesian or Balinese). The results suggest that children produce more response discourse type in their utterances due to the fact that these young language learners have very limited communicative repertoire. It seems that their conversation range primarily revolves around the typical question and answer conversational dyad. Furthermore, it has been found that young children make use of the Indonesian language in their responses more than their native language (Balinese language). This language preference may be due to the fact that children are exposed to L2 influences such as: movies, song, and other learning materials.
\end{abstract}

Keywords: discourse, language development, children's direct speech.

\section{INTRODUCTION}

It is believed that children generally have the capacity to learn to talk. This predisposed tendency to acquire language is a genetic inheritance that is part of humankind's physiological growth and development. About the age of one, the young language learners will utter their first words. Their linguistic development is so fast than adults cannot help but marvel at this remarkable natural biological phenomenon.

There are several major linguistic conditions for the development of language among novice learners. First, children must be able to recognize and organize sensory information that is made available to them. They must be able to distinguish and then extract the linguistically important and significant sounds that the adults and heir immediate environment provide them

Secondly, speech comes to children as a continuous sound wave: children must be able to segment, categorize and organize this learned linguistic information according to their semantic value. The acts of segregating and categorizing are pertinent attributes of the language that children must be able to organize for successful language learning.

The third condition for linguistic development involves meaning. The young language learners must be able to recognize that the adult speech they are exposed to is motivated by intention to produce meaningful sounds.

These linguistic stage are activated to a series of stage that are regulated and controlled by a natural human biological clock; beginning even before birth. The initial stage is constant in all young learners. As the processing of speech becomes more complete and more complex, the variety of available responses increases. The 
uniqueness of language learning depends on the individuality of the children but this will not prevent them from readily achieving full knowledge of their first language as the Nativists argue in their position that children are pre-disposed to learn their native language.

By and large, speech for children is the physical host of information that they receive about the structure of their language as provided by their adult companions and their immediate environment. Speech also has another essential purpose for children communication (de Boysson-Bardies, 1999).

Communication should not be confused mainly with the faculty of language. Language can also be perceived as the expression of thought through a structured system, which is more than a privileged means of communication. It is a system of communication specific to man. Humans have other means of communication - facial gestures and expression and several body movements. Through these nonverbal pathways, children receive information from the people around them and convey this acquired information to other people even before they learn to speak. Thus, children become part of the web of communication necessary for their survival.

In a very short span of time, children are able to make linguistic developments in the phonology, lexicon, and grammar of their language. These linguistic accomplishments provide the novice language learner with a system for expressing meaning by producing sequences of sounds. Children utilize this system to communicate with others.

In the first five years of life, as children are acquiring language, they are also developing communication skills. As children's language abilities progress, language becomes the primary vehicle of communicative acts. Conversational skill begins to develop during the second year of life as children learn the mechanics of verbal interaction, such as taking turns, initiating topics, repairing miscommunication, and responding continently. Initially, children's conversations with adults are very asymmetrical, with adults doing the work of building conversations around children's contributions. As children's conversational skill develop, the relative burdens carried by the adult and the child in sustaining conversations become equal.

The current study focuses to answer the following questions: (1) What are the various discourse types used by Balinese preschool children in their directed speech? (2) What is the predominant discourse type used by young language learners in their utterances? And (3) In what language is the identified speech style more preponderant?

\section{METHOD}

\section{Research Design}

The data for the study involved naturalistic recording of interactions between four-year-old children and their adult companions or caregivers (father, mother, kakek (grandfather), nenek (grandmother), or mbok (nanny). The children's data was taken from the writers 'neighborhood especially four years old preschool children with their adult companions or caregivers. Only the children's utterances were analyzed to identify the different discourse styles they used in their interactions. 


\section{Participants}

The young participants in this study are 10 preschool four-year-old boys and girls. The young subjects are Balinese residing in the Perum Multi Banyuning Lestari area. The subjects are young learners who can speak both Balinese and Indonesian languages. The adult's participants are the adult companions or caregivers of the children. They can be the mother, father, kakek (grandfather), nenek (grandmother), or even the mbok (nanny) who spend long contact hours with the children at home. The adults are also speaks both Balinese and Indonesian.

\section{Procedure}

The existing corpus of children and adults' transcriptions involved the naturalistic recording of their conversations. The interactions between the young language learner and the adult caregiver were recorded for $15-25$ minutes. The subjects were instructed to hold conversations while they were playing, studying, eating, watching television, or even doing their household chores.

\section{Method Analysis}

After transcribing and encoding, the data were coded and manually counted to identify the following variables:

a. Discourse types used by the children

- Narrative

- Interrogative

- Hint

- Request

- Ritualized response

- Apology

- Response

- Greeting

b. Language used by children in their utterances

- Balinese

- Indonesia

- Code switch

Only the utterances of the children were analyzed in this study. The identified discourse types found in the children's utterances were manually counted.

\section{FINDINGS AND DISCUSSION}

In general, the finding from the present study showed that Balinese children in Perum Multi Banyuning Lestari Singaraja utilize the response discourse types in their utterances. Very young language learners have very limited discourse knowledge and it seems that their conversation range primarily revolves around the typical question and answer conversational dyad. It is noted in some of their conversations with the adults that response discourse types is indeed preponderant.

Example 1.

Situation: In the afternoon, when Indah practice to color the flower with her mother in her veranda. 


\begin{tabular}{|c|c|}
\hline Ibu & : Ya benar...., trus apa warna bunganya tu geg? \\
\hline & (Yes, that's right. What is the color of this flower, geg?) \\
\hline Indah & $\begin{array}{l}\text { : Yang ni Bu.....boleh ya bu ya........ } \\
\text { (This one mom.... May I use this color mom?) }\end{array}$ \\
\hline Ibu & $\begin{array}{l}\text { : Boleh...... Apa nama warna ini geg? } \\
\text { (OK... What color is it, geg?) }\end{array}$ \\
\hline Indah & $\begin{array}{l}\text { : Merah....namaya bu. } \\
\text { (It is red mom) }\end{array}$ \\
\hline
\end{tabular}

Example 2

Situation: In the afternoon when Mbok Tut called Bayu to back home

\begin{tabular}{|c|c|}
\hline Mbok Tut & $\begin{array}{l}\text { : Bayu,..... pulang mandi! Dimana tadi maen? } \\
\text { (Bayu goes home and take a bath! Where did you play just now?) }\end{array}$ \\
\hline Bayu & $\begin{array}{l}\text { : Disana mbok..... (Bayu menunjuk arah lapangan dekat warung) } \\
\text { (Over there Mbok....(Bayu notices the field near the warung)) }\end{array}$ \\
\hline Mbok Tut & $\begin{array}{l}\text { : Disana dimana? } \\
\text { (Where is it?) }\end{array}$ \\
\hline Bayu & $\begin{array}{l}\text { : Tu apa dilapangan bola deket rumahnya dik Gede. } \\
\text { (Over there at football field which near to 'Dik Gede's house) }\end{array}$ \\
\hline Mbok Tut & $\begin{array}{l}\text { : Sama sapa maen? } \\
\text { (With whom do you play there? }\end{array}$ \\
\hline Bayu & $\begin{array}{l}\text { : Ada Kak Dewa, Beni, Dik Gede juga ikut..... } \\
\text { (There are Kak Dewa, Beni, and also Dik Gede) }\end{array}$ \\
\hline
\end{tabular}

Example 3

Situation: When Pak Putu taught Danu about color in his house

\begin{tabular}{|c|c|}
\hline Pak Putu & $\begin{array}{l}\text { : Bener, trus yang mana yang sama? } \\
\quad(\text { That's right, which one are the same?) }\end{array}$ \\
\hline Danu & $\begin{array}{l}\text { :Yang ini sama yang ini....... } \\
\text { (This one with that one) }\end{array}$ \\
\hline Pak Putu & $\begin{array}{l}\text { : Kok bisa sama? } \\
\quad \text { (Why they are the same?) }\end{array}$ \\
\hline Danu & $\begin{array}{l}\text { : Liatin nae warnanya sama biru, tau! } \\
\text { (Look, both colors are blue) }\end{array}$ \\
\hline
\end{tabular}

The example illustrated shows that normally the adult will initiate the conversation through the use of questions to elicit the response from the child. As observed by Furrow, Nelson \& Benedict (1979); Hoff-Ginsberg (1986) in their studies, as far as the area of pragmatics is concerned; adults make use of interrogatives to elicit responses from their children. These interrogative types of questions are characterized as "quiz" types to get responses from children. Most of the questions follow the "WH" format (what, when, why, were, who and how) that more or less cue children to provide answers to whatever queries the adults may have. Another example from the data collected will apply how interrogatives can help children in the elicitation of responses: Example 4 
Situation: In the Gede's garden.

\begin{tabular}{|c|c|}
\hline Bapak & : De liat ni.... Apa namanya ni De....? \\
\hline & (De look this one,..... What is it De...?) \\
\hline Gede & $\begin{array}{l}\text { : Kupu - kupu, bui .... gede kali pak....... } \\
\text { (Butterfly, wow it's very big, pa .....) }\end{array}$ \\
\hline Bapak & $\begin{array}{l}\text { : Seratus untuk Gede! Brapa banyak kupu - kupunya De? } \\
\text { (Very good De! How many are the butterflies, De?) }\end{array}$ \\
\hline Gede & $\begin{array}{l}: \text { Ya dua lah pak.... } \\
\text { (There are two, pa...) }\end{array}$ \\
\hline
\end{tabular}

Example 5

Situation: In the living room, when Dedek was watching Sponge Bob

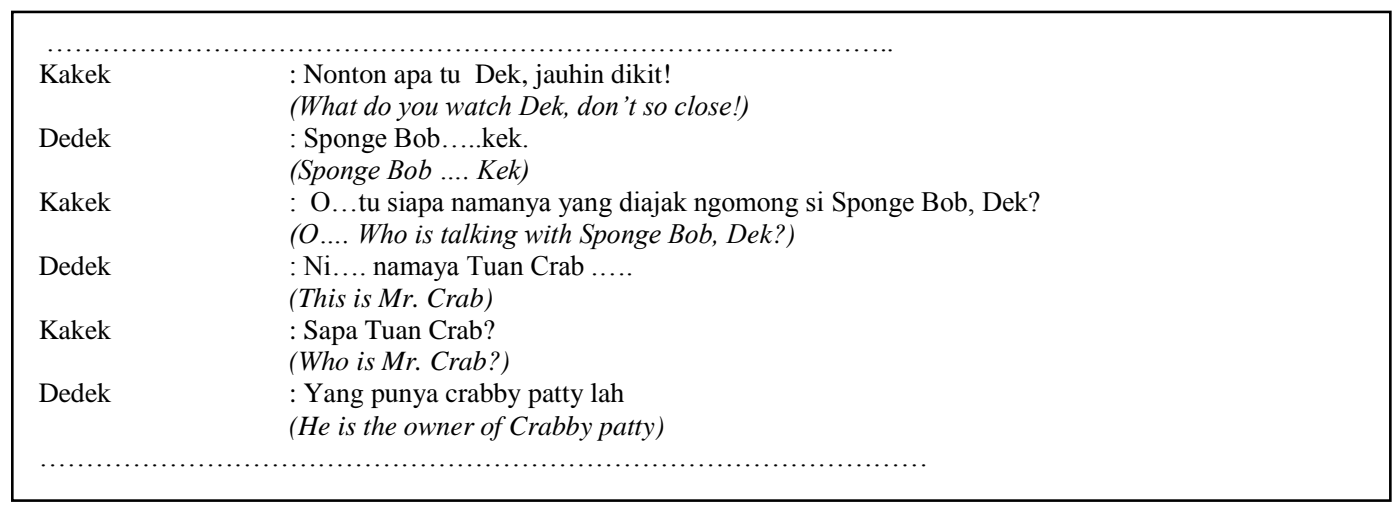

Example 6

Situation: In the Arik's house

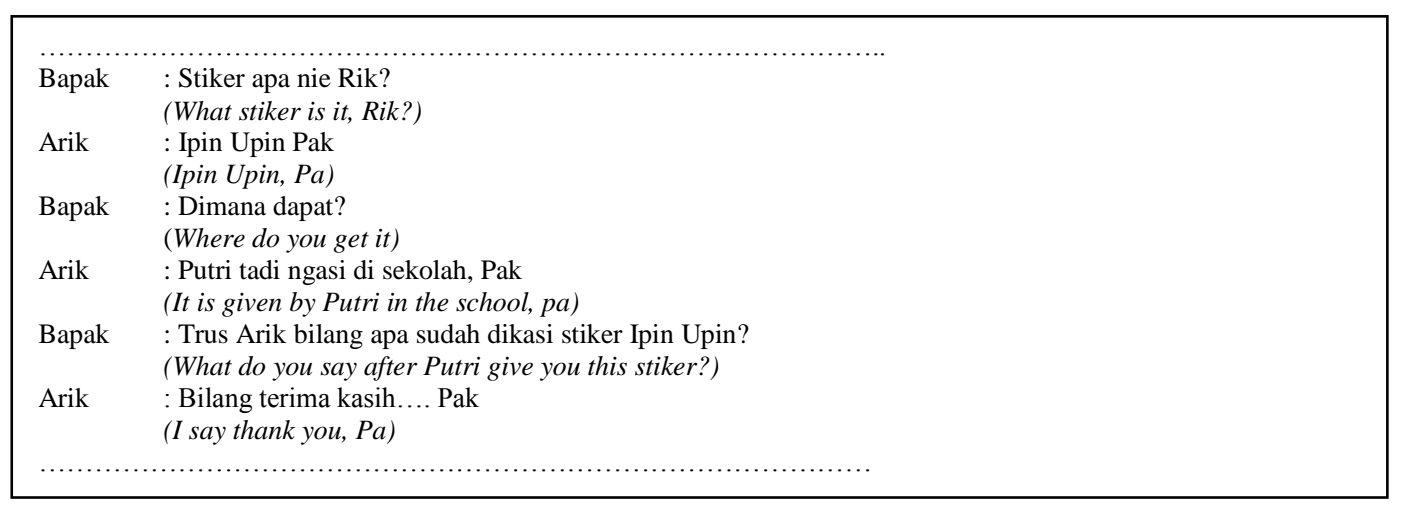

The above situation also shows that many of the responses produced by the young respondents are in the Indonesian language. This may be due to the fact that some Balinese parents prefer their children to speak in Indonesian early on. Even grandfather and other members of the extended family are obliged to use Indonesian language when conversing with the children. What is interesting in the result is the fact that the participants are Balinese children belonging to the middle class and that they use both Balinese and Indonesian in their conversations. Moreover, it can be noted that Indonesian is the preferred language over the Balinese language. It may be due to the exposure of children to watch Indonesian cartoons in National TV programs like: RCTI, 
SCTV, Space Ton, etc rather than watching traditional program "mesatwa Bali" in local TV program (Bali TV program), videos, and other learning materials which can be easily understood and also made available to the public today.

The next situation illustrates that even if the adults use the Balinese language to ask their questions, the children still use Indonesian language when they respond the queries:

Example 7

Situation: When Mbok Tu asked Bobi to have lunch in Bobi's house

\begin{tabular}{|c|c|}
\hline \multicolumn{2}{|c|}{ Mbok Tu : Mangkin maem Gus.....? } \\
\hline & (Do you want to eat, Gus?) \\
\hline Bobi & $\begin{array}{l}\text { : Beh bentaran aja mbok..... } \\
(\text { No, later on,... Mbok) }\end{array}$ \\
\hline & $\begin{array}{l}\text { Mbok } \mathrm{Tu}: \text { Ye... Welange nyan jak Ibu! } \\
\text { (No, your mother will angry with you) }\end{array}$ \\
\hline Bobi & $\begin{array}{l}\text { : Ndak mau... bentaran ja habis Kapten Tsubasa } \\
\text { (No... later on after Kapten Tsubasa) }\end{array}$ \\
\hline
\end{tabular}

Example 8

Situation: In Dewik house

\begin{tabular}{|c|c|}
\hline Ibu & $\begin{array}{l}\text { : Nyen ngelah mainanne di terase Wik...? } \\
\text { (Who has this doll in the verandah, Wik?) }\end{array}$ \\
\hline Dewik & $\begin{array}{l}\text { : Kak Putri.... Mak. } \\
\text { (Kak Putri ..... Ma) }\end{array}$ \\
\hline Ibu & $\begin{array}{l}\text { : Adi dini jang? Pindahin...... ilang nyanan. } \\
\text { (Why does she put here? Take it.....) }\end{array}$ \\
\hline Dewik & $\begin{array}{l}\text { :Ya bu.......... } \\
\text { (Yes ma...) }\end{array}$ \\
\hline
\end{tabular}

Example 9

Situation: In Tu Diah's house

\begin{tabular}{|c|c|}
\hline Kakek & $\begin{array}{l}\text { : Tu ... tolong jemakang kacamata kakek duur mejane } \\
\text { (Tu.... Help me. Can you take my glasses on the table, please!) }\end{array}$ \\
\hline Tu Diah & $\begin{array}{l}\text { : Ya bentaran kek habis Dora } \\
\text { (Yes, but wait a minute after Dora finish) }\end{array}$ \\
\hline Kakek & $\begin{array}{l}\text { :Ye.... enggalin nae kakek mau baca....!. } \\
\text { (Come on, hurry up kakek wants to read!) }\end{array}$ \\
\hline Tu diah & $\begin{array}{l}: \text { Yа.............. } \\
(O k \ldots . . .0 k \ldots .)\end{array}$ \\
\hline
\end{tabular}


Example 10

Situation: In Mang Nanda's dining room

\begin{tabular}{|c|c|}
\hline Ibu & $\begin{array}{l}\text { : Be suud maem Mang? } \\
\quad \text { (Have you finished your food, Mang?) }\end{array}$ \\
\hline Mang Nanda & $\begin{array}{l}\text { :Sudah bu..... } \\
\text { (Yes ma....... }\end{array}$ \\
\hline Ibu & $\begin{array}{l}\text { : Buin nambah maeme? } \\
\text { (Do you want to add more?) }\end{array}$ \\
\hline Mang Nanda & $\begin{array}{l}\text { : Ndak sudah kenyang...... } \\
\text { ( No, I'm full) }\end{array}$ \\
\hline
\end{tabular}

Those examples clearly illustrate the preference of young children to use the Indonesian language in their responses. Even, if adults make use of Balinese or code switched form in eliciting responses from the young language learners, children give their responses in Indonesian

\section{CONCLUSION}

Since young language learners have limited knowledge of the things around them, they may have difficulty sustaining conversations with the adults. Thus, children are dependent on their adult to initiate conversations through elicitations of responses from them. The study has verified the findings of previous studies regarding the preponderance of responses in the young Balinese learners' communicative and pragmatic development.

The present study also yields almost the same speech acts present in children's conversations with the respondents' adult companions. The current study finds the following speech types in children's utterances as being dominant: narrative, interrogative, response, hint, request, and ritualized response. Moreover, responses are the preponderant speech type present in children's conversation. The findings of the study suggest that due to the limited knowledge and communicative skills of very young children, they have more responses than questions to ask or than requests, hints or even narratives in their early discourses.

As a whole, this study also shows that the responses elicited by adults from the children are in Indonesian, even if the questions are addressed using the Balinese language or its code switch form, children have the tendency to use the Indonesian language more than Balinese. This may be due to the Balinese children's exposure to watch National TV programs like: RCTI, SCTV, Space Toon, etc rather than local TV program (Bali TV program), videos, and other learning materials. Besides, parents of these children also reveal that Indonesian is used at home as a medium of communication apart from the mother tongue, which is Balinese.

Finally, this study would like to suggest that children's communicative skill development do not end at pre-school, when these young language learners are not yet fully communicatively competent. The improvement of discourse and communicative skills may be lifelong developmental tasks that all human beings must constantly develop. Moreover, the study also presents the preponderance of the use of Indonesian language over the Balinese language as reflected in the early interactions of children with their adult caregivers. 


\section{REFERENCES}

Chapman, R.S. 1981. Exploring children's communicative intents. In E. Hoff (Ed), Language development. Belmonth: Wadsworth-Thomson Learning.

De Boysson-Bardies, B. 1999. How language comes to children: from birth to two years. Cambridge: MIT Press.

Hoff-Ginsberg, E. 1986. Function and structure in material speech: Their relation to the child's development of syntax. Developmental Psychology, 22 (2), 163-166.

Hoff, E. 2001. Language development. Belmonth: Wadsworth-Thomson Learning.

Lucas-Garcia, R.I. 2004. Exploring noun bias in pre-school bilingual children. Unpublished dissertation. De Le sale University-Manila, Philippines

Newport, E.L., Gleitman, H., \& Gleitman, L.R. 1977. Mother, I'd rather do it myself: some effects and non-effects of maternal speech style. Talking to children: Language input and acquisition. Cambridge: Cambridge University Press.

Searle, J. 1969. Speech Acts: An Essay in the Philosophy of Language. Cambridge: Cambridge University Press 